\title{
172 VARIA \\ Human on fire as a gesture of self-offering in Polish documentary films
}

\author{
URSZULA TES \\ The Institute of Cultural Studies \\ Jesuit University Ignatianum, Krakow
}

\begin{abstract}
Tes Urszula, Human on fire as a gesture of self-offering in Polish documentary films "Images" vol. XXV, no. 34. Poznań 2019. Adam Mickiewicz University Press. Pp. 172-179. ISSN 1731-450X. DOI 10.14746/i.2019.34.12.

One of strongest acts of personal protest in the communist era was self-immolation, which was the subject of two Polish documentaries. Maciej Drygas in Hear My Cry invoked the figure of Ryszard Siwiec, who immolated himself on September 8, 1968 as a sign of protest against the Soviet army invasion of Czechoslovakia. In his documentary, Drygas shows a fragment of the film with the burning man, juxtaposing it with the testimony of witnesses to the tragedy and the account of the family. This documentary restores the memory of the whole society, who due solely to the film, learned about the radical gesture of a common man. Holy Fire by Jarosław Mańka and Maciej Grabysa in turn invokes the heroic but forgotten Walenty Badylak, who immolated himself in March of 1980 in Cracow as an expression of his objection to distortion of the truth about Katyń. Both acts of self-immolation had for many years been perceived as totally futile acts, while the directors show that the self-immolation of these now has a deep and symbolic meaning. In my analysis, I shall invoke historic and cultural contexts, conduct a multifaceted interpretation of self-immolation act and discuss the complex imagery included in the films.
\end{abstract}

KEYWORDS: self-immolation, documentary film, history of Poland

In my article, I am going to outline the issue of self-immolation as an extreme form of political protest by embedding it in a broader historical and cultural context. Two stories shall exemplify the problem: those of Ryszard Siwec and Walenty Badylak, who became heroes of documentary films. The issue of self-immolation was thoroughly studied by American, and recently by Polish, researchers. A few significant publications appeared about one film (Hear My Cry), which shall be the subject of my deep analysis; however, none of them raise the topic against the historical and cultural background. Holy Fire (Święty ogień, 2011), a reportage, has not been written about so far, and the figure of Walenty Badylak still remains unknown, despite a strongly-developed historical policy in Poland. In the introduction, I am going to present general remarks concerning

[1] E. Durkheim, Samobójstwo, trans. K. Wakar, Warszawa 2011. the act of self-immolation; subsequently, I shall portray Ryszard Siwiec and refer to the film Hear My Cry (Usłyszcie mój krzyk, 1991). Finally, I shall evoke Walenty Badylak's story and a barely known documentary devoted to his act. Reminding the world of the remarkable sacrifice of these two men is the major objective of my article. Through analysis of the films, I intend to show the power of documentaries as such.

Self-immolation, as an act of political protest, is a specific kind of suicide, which can be perceived in terms of the sacrifice of an individual in the name of higher values and social ideals. It is altruistic suicide resulting from an extremely strong relationship of an individual with the society, as Émile Durkheim describes in his sociological study.[1] Rarely has self-immolation been treated as an act of self-destruction, but rather an honorable and admirable act. However, it should be pointed out that suicide itself is burdened with lots of 
negative connotations which have undergone transformations in the course of time and the development of culture. Nowadays, diverse factors leading to suicide are taken into account. As written by Polish researcher Robert Kulmiński, self-immolation is a drama - the most spectacular of all ways of taking one's own life. The intention of protesters who chose this dire form of defiance was to seek the biggest possible audience. In consequence, society was to become a community of viewers focused on one common object, namely the human on fire. Multiple acts of self-immolation were carefully planned and even directed. Those committing suicide precisely selected the location and stage where their drama would be held.[2] Michael Biggs, an American sociologist, estimated that in the years 1963-2002, there occurred three thousand self-immolations all over the world (including the ones not ending in death).[3] Unfortunately, among the most spectacular acts of self-immolation, he did not mention two committed by Poles Ryszard Siwiec and Walenty Badylak. In my article, I shall invoke these two men, making references to their biographies, Polish history and documentary films. I shall pay particular attention to Ryszard Siwiec, who was the first person in the post-war history of Eastern Europe to commit the act of self-immolation in the name of politically-motivated reason. This act, relatively unknown in Poland and Europe, was saved from oblivion by a Polish documentary filmmaker, Maciej Drygas, who in 1991 made a film called Hear My Cry. Before discussing this documentary film, I would like to present the protagonist's profile.

\section{Story of Ryszard Siwiec's life}

Ryszard Siwiec was born in 1909 in Dębica; he spent his childhood in Lviv, where he graduated from secondary school and got a degree in philosophy. In 1936, he moved to Przemyśl, where he worked in a tax office; however, after the outbreak of WWII, he resigned from his post, as he did not intend to work for the occupiers. During the war, he served in the Home
Army. His attitude towards communism, an attitude which began to prevail in Poland in 1945, was very critical. Siwiec did not accept the post of a history teacher because he knew that it would involve indoctrination. Until his death, he remained an accountant. He had a wife and five children. According to his family and friends, he was profoundly moved by the political situation in Poland and the world and spent whole days listening to the Free Europe Radio. The events of March 1968, when students' protests were suppressed and an anti-Semitic campaign initiated, he took as a personal defeat. As a form of disagreement, he chose to edit anti-system leaflets, signed "John Pole", which he distributed with his daughter's help. However, the most painful experience for him was the invasion of Warsaw Pact Army in Czechoslovakia in August of 1968, which eventually led to the dramatic decision of self-immolation. Despite Communist propaganda, Polish society considered the participation of the Polish army in the Czechoslovakian events a disgrace. Nonetheless, public acts against the invasion were avoided for fear of repressions. Ryszard Siwiec, in complete loneliness, chose an extreme form of opposition against totalitarianism, communist crimes, aggression and human rights violations in Poland and the neighboring Czechoslovakia.

Self-immolation is alien to European tradition, which is why numerous researchers believe that Siwiec might have been inspired by Buddhist monks opposing the religious policy of Southern Vietnam. In 1963, Thich Quang Duc set himself on fire on a busy crossing in Saigon and soon the photograph documenting this event was seen by the entire world. Interestingly, the monk did not refer to his act as suicide, but substitute sacrifice, which should move hearts and lead to changes, which for

[2] R. Kulmiński, Tu pali się ktoś, Kraków 2017, p. 35.

[3] M. Biggs, Dying Without Killing. Self-Immolations 1963-2002, <http://users.ox.ac.uk/ sfosoo6o/immolation.pdf $>$ [accessed: January 10, 2019]. 
Ryszard Siwiec could have been an important argument. [4] What this modest man did was an act of overcoming human limitations - fear of death, severe pain and finally, the condemnation of church and society - which for a practicing Catholic believer was undoubtedly a substantial dilemma. Ryszard Siwiec carefully prepared all the details for many months ahead of his self-immolation; he wrote his last will, and a few days before the incident, made arrangements to enter the 1oth Anniversary Stadium in Warsaw. He also recorded his message and prepared anticommunist flyers. Moreover, he had his photograph taken, and on the way to Warsaw, wrote a goodbye letter to his wife (it was intercepted by the security service, and his wife received it 20 years later). Siwiec had a precise scenario of his death; he even changed the allocated sector at the stadium to be better visible from the main tribune, where party leadership, together with Władysław Gomułka, First Secretary of the Central Committee of the Polish United Workers' Party, and Józef Cyrankiewicz, the Prime Minister were sitting. Siwiec chose an exceptionally spectacular moment; the celebrations of the Central Harvest Festival were attended by over one hundred thousand people, including representatives of authorities, foreign guests and the media - press, radio, TV. The Central Harvest Festival was a very significant propaganda event in the period of the PRL because the party leader played the role of head of state, who addressed the nation, and at the same time was paid tribute by representatives of rural communities, which were considered the second most important social class beside workers. Harvest celebrations were originally held as folklore festivities, consisting of participation in different traditional customs, but in

[4] P. Blažek, Polska żywa pochodnia, [in:] Ryszard Siwiec. Pro memoria, ed. R. Brzostowski, M. Zemło, Tarnów, Dębica 2015, s. 48.

[5] R. Zych, Tragiczna śmierć Ryszarda Siwca - kres czy poczatek?", [in:] Ryszard Siwiec. Pro memoria, ed. R. Brzostowski, M. Zemło, Tarnów, Dębica 2015, p. 8o.

[6] P. Blažek, op.cit., p. 52. communist times, their ranks grew to a massive spectacle, in which folk groups sang and danced. It was an opportunity to present economic success. One of the authors of the book Ryszard Siwiec. Pro Memoria wrote: "Death of a lonely, full of determination man during a socialist celebration of harvest festival, death among falsified symbols of Proto-Slavonic harvest festivities became a real and tragic harvest of the totalitarian state".[5]

We shall never know why Siwiec did not begin his protest during the First Secretary's speech, but only later, when a group of young people in folk costumes appeared on the main pitch and initiated the Polonez dance. When he was on fire, he started shouting: "Long live free Poland" and "This is the scream of a dying free man"; he did not allow anyone to put out the fire, and he wanted someone to open his briefcase with the flyers. The protest of Ryszard Siwiec was seen by hundreds of people, yet none of them undertook to uncover the truth or could understand the sense of this desperate act. Undercover security service members and the militia very quickly led him out of the stadium to a car and took him to the hospital. Nobody, except for his wife and cousin, was allowed to visit the seriously burnt man. The room, where Siwiec was lying in solitary confinement, was bugged, and thanks to this fact, we know his last words: "I'm dying for the truth to win, for humanity to win and for love to win. I don't feel pain and I felt it at no time." [6] This moving message indicates Siwiec's constant consciousness, but also his special state of mind, which reduced the dreadful pain of extensive burns. Doctors and nurses could not believe that a person in such a severe condition was still alive, and what was more, able to answer questions. His agony lasted four days unnaturally long. After Ryszard Siwec's death, the investigation of his case was quickly closed. For a couple of days, a story about a man who immolated himself during the harvest festival was circulating in Warsaw, but nobody knew the circumstances of this incident. In Przemyśl, where Siwiec lived, the security service spread 
rumours about his alleged alcoholism or mental illness, which were supposed to discredit him. Due to this, many acquaintances turned away from the mourning family. The Polish press did not report this dramatic event. Security services confiscated films with images of a man on fire. Secret police officers disseminated among the witnesses of the self-immolation information that the man was drunk and that the fire started because he spilled alcohol on himself. This false rumor appeared plausible for many, since nobody understood the meaning of self-immolation as a political protest. Free Europe Radio broadcasted the information about Siwiec's shocking act much later, in 1969, a few months after a Czech student, Jan Palach, immolated himself. The information about Siwiec's self-immolation received by the management of the radio was unconvincing. The memory of the hero, who sacrificed his life in the name of higher values, almost entirely faded. The only trace left was a brochure commemorating the tragically deceased man, published in 1981 by his family at their own expense. Even after the fall of communism, the sacrifice of Ryszard Siwiec was not remembered, and it was only in 1991, that the documentary film Hear My Cry by Maciej Drygas depicted this outstanding figure and his distinctive act.

\section{Hear My Cry - recovering memory of Siwiec's act}

The director learned about the self-immolation of Ryszard Siwiec in 1989 from a newspaper and instantly became interested in the topic: he began his search for witnesses, he approached the family and found archival materials, including an invaluable seven-seconds-long film depicting the burning Siwiec. The latter was discovered in the archives of the Documentary Films Studio among rejected materials. The director felt a great responsibility for the topic, because he knew that thanks to his film, Siwiec's heroic act would reach the collective consciousness. The filmmaker himself talked about it as follows:
The extensive documentary material required finding a dramaturgic key, which could effectively build up higher levels of meaning. It was not my intention to make a journalistic or educational film [...]. I felt a great moral responsibility. I knew that my vision will affect further perception of Siwiec's act, its historical and above all emotional reception. Self-immolation was not part of Polish heroic tradition. I could not count on historians' help, because the whole documentation was in my hands.[7]

The black and white film begins with a prologue, in which from a distance we can see militiamen carrying out archives, which are later burnt. The image of burning paper is juxtaposed with a shot of a monotonously swaying crowd, followed by a portrait of Ryszard Siwiec in some home interior. This is a visual metaphor of erasing an unbroken hero from the collective memory. The motif of fire comes back at the end of the film, bonding the whole with a symbolic brace, while the motif of society in lethargy disappears, when handwritten words "Hear My Cry" can be seen on the screen. It is a significant maneuver from the director - in this way, he implements a personal perspective. In subsequent scenes, the author alternately shows scenes recorded in 1968 during the Central Harvest Festival at the 1oth Anniversary Stadium and those recorded nowadays in various archives: the Office of Internal Affairs, the hospital of the Transfiguration of the Lord, the Military Public Prosecution and church we learn that the archives will not reveal the truth, since the files of Ryszard Siwiec's case were either destroyed or falsified reality. Afterwards, the director focuses his attention on people who knew the hero. The emerging picture shows Siwiec as a man passionate about history, a bibliophile, who deeply experienced his loathing for the totalitarian system to which the society succumbed. Inner tension and defiance steadily grew in Siwiec. The clash of im-

[7] M. Drygas, Analiza warsztatowa filmu dokumentalnego 'Ustyszcie mój krzyk', "Images. The International Journal of European Film, PreformingArts and Audiovisual Communication" 2015, vol. XVI no. 25, p. 151. 
ages depicting young people in folk costumes dancing rhythmically and statements revealing the hero's state of mind create a deliberate dissonance - lucidity versus lonely consciousness. The scenes from his home in Przemyśl are like entering Siwiec's private space. While hearing the text of his will read off-screen, we successively meet his wife Maria Siwiec and his five, now grown-up, children, some of whom live in Canada. Each of them reflects on their father's and husband's act - understanding and admiration intertwined with the feeling of great loss and grief. One of the sons calls his father the authority. Ryszard Siwiec wrote in his last will that he wanted to protest "against the total tyranny of evil and lies which conquered the world" and ended with words addressed to his children: "And you my dear children, never let someone take away your faith in God and belief in human in pursuit of freedom and truth that's what I recommend and order." [8]

The first part of the film is crowned with the utterance of Józef Tischner, a priest and philosopher, who did not know Ryszard Siwiec and did not witness his self-immolation. $\mathrm{He}$ invokes the examples of Buddhist monks, who by self-immolation wished to express something significant, for which this act contained a creative element. The priest appears in the film twice, marking two important turning points in the structure and, according to the intention of the director, plays a role similar to a Greek chorus.

In the second part of the film, the director travels from Przemyśl to Warsaw by train and covers the same route as Ryszard Siwiec did to the Stadium. During the journey, we can hear words of the letter he wrote to his wife on the train, read by a Security Service officer off-screen. The elevated tone of the letter confronted with unemotional voice create a dissonance. Finally, the filmmaker holds a series of

[8] Quotations from Maciej Drygas's film Hear My Cry.

[9] Quotation from Maciej Drygas's film Hear My Cry. talks with the witnesses of the self-immolation of Ryszard Siwiec in the scenery of an empty Stadium. A radio journalist, militiaman, dance instructor, operator of Polish Newsreel, photojournalist, doctor, nurse, firefighter, all witnesses to the act speak in front of the camera. Drygas characterizes these people not only through words and gestures, but also clothes and attributes indicating their professions (camera, microphone, etc.). This is a crucial part of the film; from what the people are saying arises the image of a collective captive mind, which could not allow thoughts of a fight for freedom. Each witness tries to justify their passivity and indifference to the tragic event; the radio journalist says that it was unimaginable to stop the broadcast of the performance accompanied by cheerful music and inform listeners about an unsettling incident. Dance instructor did not want the dancing youths to be distracted by the image of a man on fire; the camera operator believed that he could not have any emotional attitude to the sight of a burning man, which he saw from a distance through the lens of his camera. Of note is what a doctor said in his account of the medical staff's attitude towards Ryszard Siwiec:

When my colleague gave the reason why the man had burns, some said - madman, psychopath and so on. Another colleague hearing that said angrily: the Polish nation was brought up in this way and we were all so indoctrinated that when Buddhist monks immolate themselves, we consider them saints, but when somebody sets himself on fire here for certain reasons, let us say political ones, then we say he is crazy.[9]

These utterances reveal witnesses' beliefs and principles, shaped to a large extent by communist propaganda. Human compassion was replaced by loyalty to the rules, prohibitions and orders of the authorities. The director lets us feel strongly about why nobody heard the voice of this protester; the self-immolation of a man was an uncomfortable gesture, which awoke the society from its sleep. The best defence against understanding this act was to erase it from consciousness and let it fade into 
oblivion. The witnesses' utterances are again illustrated with archival photos, but this time shown differently, and they play another role. While in the first part of the film we saw realistic images of cheerful dances, now the image is distorted - figures are elongated, and the pace of movement is slowed down. Dancers freeze, awaiting something; instead of joy, they have a look of anxiety on their faces. The intention of the director was to make the pageant resemble a funeral procession. The images of the dance bring to mind a literary motif of the straw effigies' dance, which present in Polish culture, and also in Polish cinema (eg. Wedding [Wesele], 1973) originally from Stanisław Wyspiański's drama of the same title. The protagonists, participating in this dance, become a symbol of malaise, opportunism or the indifference of society.

In the final part, we can see 7 seconds of archival film divided into phases. Initially, we observe a close-up of spectators' reactions; they stand up from their seats, looking at one specific point. Somebody covers his mouth; another person clutches his head in disbelief. Then, there are people running in panic. We are to be witnesses to the drama that is happening off-screen. The tension is gradated and the climactic moment is extended indefinitely by the director. These slowed down images are interwoven with shots of speakers - family members, acquaintances, witnesses, a priest and in the end, we can hear off-screen the voice of Ryszard Siwiec himself, who, two days before his self-immolation, recorded an appeal to the nation, ending with the words: "People, who may still have a spark of humanity, human feelings, come to your senses! Hear my cry, the scream of a common, ordinary man, a son of the nation, who above all loved freedom, more than his own life, come to your senses! It is not too late yet!" [10] Only at the very end does the director show the figure of the burning Siwiec, who is waving his hands and screaming, but it is a silent scream. The freeze frame is on the face, which is full of triumph and passion. This is the culminating moment, playing the role of catharsis. The self-immolation of Siwiec was metaphorically commented on by the priest Tischner, who said that it was freedom that burnt at the Stadium, not in the sense of destruction, but of light: "Some enormous light of freedom appeared. As a matter of fact, it was a man free from earthy constraints and this freedom was a blow to totalitarianism." [11]

Maciej Drygas, both in his film Hear My Cry and the radio documentary Testament, which were distributed all over the world from the USA to Australia, raised from obscurity the heroic act of Ryszard Siwiec. His name ultimately has found a place in Polish school-books. Moreover, his protest raised awareness of Czechs and Slovaks, which is evidenced by publications about and highest state distinctions awarded to Siwiec posthumously.

\section{Holy Fire - a forgotten story}

Twelve years after Siwiec's self-immolation, on March 21, 1980, Walenty Badylak set himself on fire in the Market Square in Cracow. In this way, the 76 -year old man protested against the falsified information about the murders in Katyn', committed by the Soviets in 1940, of ten thousand Polish army and police officers, who were considered enemies of communism. Badylak, born in 1904, fought in the Home Army during WWII, like Siwiec, and all his life cultivated patriotic traditions. As a baker, he could not accept the communists' destruction of private businesses. His personal tragedy was an ideological conflict with his son, who, prompted by his Silesian mother declaring German citizenship during the war, joined the Hitlerjugend. After the war, Badylak's son was recruited by communist counterintelligence. His father considered this decision immoral and broke off contact with him.

In Holy Fire, a documentary film from 2011 directed by Jarosław Mańka and Maciej

[10] Quotation from Maciej Drygas's film Hear My Cry.

[11] J. Tischner, Myśmy tej śmierci nie przemyśleli, "Kwartalnik Filmowy" 1993, no. 1, p. 43. 


\section{VARIA}

Grabysa, Badylak, a character almost completely unknown to Poles, was presented. The film includes not only the remembrances of people who knew him or were witnesses to the act, but we can also hear off-screen a former officer of the secret service, who explains how in communist times, historical truth was falsified. Besides, he provides some insight into the difficult relationship between father and son.

Archival photographs from the site of the event play a crucial role in the film. We can see deeply shocked, extremely focused or anxious people. The photographer who took the pictures had a sense of mission to document this traumatic act, although some wanted to grab his camera and beat him. His statement is quite remarkable: "I believe that in this gesture (self-immolation - UT), he was both a hero and prophet, and in the subsequent couple of days, he was a spiritual leader of the nation." [12] Graphic close- ups of his burnt body come back several times in the film, as does the image of a match being lit. Communist authorities tried to undermine Badylak's sanity and in a short note in a newspaper, he was described as mentally ill. Despite this fact, Cracow citizens would come to the well by which Badylak set himself on fire and lay flowers and light candles. Photographs of Cracow's contemporary Market Square with a focus on the well play a significant role in this documentary film. A lot of passers-by are unaware of the dramatic event which took place here, in spite of an information board. Holy Fire is a television documentary; it lacks the refined form of the film by Drygas, yet it remains an important study of memory.

The film Holy Fire does not include a single image of Walenty Badylak. Interestingly, we cannot even find one in internet resources. We become familiarised with the story of a man who committed an act of desperation in the name of his values and principles, but we cannot give him individual features. The creators of the film attempted to fill this empty space with

[12] Quotation from Jarosław Manka's and Maciej Grabysa's Holy Fire. fictionalized pictures showing an actor dressing up, browsing books on the bookshelf, and finally lighting a match. The only existing reminders of Badylak are photographs taken by Stanisław Markowski of the crowd grouped around the self-immolation place and the plaque on the well, which bears the name Badylak's Well.

Both Maciej Drygas and the creators of Holy Fire brought a sense of realism and drama to the presented events by using various dramatic devices. The director of Hear, through film editing and scenography, gradually unveiled Siwiec's secret until the final, climactic image of a burning figure. By contrast, Mańka and Grabysa utilized a more conventional formula typical of sensational films; namely, in the soundtrack, we can hear sounds building tension, and in certain film frames, there appear inscriptions from a typewriter, together with its characteristic rattle, meant to simulate an interrogation scene. The creators of these two films use the same leitmotiv, fire: Drygas in the opening and final sequences, while in Holy Fire, we repeatedly watch shots of the lighting of a match and in the penultimate shot, flames. Significantly, both creators of the film from 2011 evoke the image of Siwiec on fire. This combination of two dramatic events creates an analogy, not only due to the type of death Siwiec and Badylak chose as a form of protest. They both set themselves on fire as a sign of political disagreement about the lies fed to the society by communists. Their sacrifice was unspoken and consistently erased from history.

Drygas and the makers of Holy Fire did not show their characters' lives against the background of "great history". We only learn about it from their relatives, acquaintances, and witnesses to the events. Subjective coverage builds an interesting sociological narrative - we get to know the attitudes of opponents and the creators of the political system, as well as the socalled "common men". The state of awareness of people in the late 6os (Hear my Cry) and early 8 os (Holy Fire) is reproduced from a long distance of time. It implies a more critical overview of events, but also a selective memory. In Drygas's film, the memory of Siwiec is invoked not 
only in oral stories, but also in personal objects, photographs, letters, and recordings, while the filmmakers of Holy Fire did not possess their subject's memorabilia, which makes the message less intense and does not build closeness with the subject.

Archival photographs play a significant role in both documentaries; in Dygas's film, images of harvest festivities from 1968 act as a chronicle, but on the other hand, they are also a carrier medium of an important metaphor. In Holy Fire, chronicles from the Cracow of the 8 os play a more conventional role; they just invoke the context of those times. Placing archival images of the reality of martial law in the final scene is a very interesting manoeuvre of the makers - in this way, they pointed to the climax, in which the oppressiveness of the system Walenty Badylak protested against so dramatically is disclosed.

Self-immolation is not only compelling, but is also the most daring human act. As presented herein, these heroes were saved from oblivion thanks to documentary films, and they found their rightful place in Polish history. Documentaries play a tremendous role in saving memory and in the process of shaking human conscience, which tends to be more and more indifferent to suffering. The cry of Ryszard Siwiec (the $50^{\text {th }}$ anniversary of his self-immolation was celebrated in 2018) and of Walenty Badylak should be heard all over the world. Only then will their sacrifice make sense.

\section{B I B L I O G R A P H Y}

Biggs M., Dying Without Killing. Self-Immolations 1963-2002", <http://users.ox.ac.uk/ sfos0060/immolation.pdf $>$ [accessed: January 10, 2019]

Blažek P., Polska żywa pochodnia, [in:] Ryszard Siwiec. Pro memoria, ed. R. Brzostowski, M. Zemło, Tarnów, Dębica 2015

Drygas M., Analiza warsztatowa filmu dokumentalnego 'Ustyszcie mój krzyk', „Images. The International Journal of European Film, Preforming Arts and Audiovisual Communication" 2015, vol. XVI, no. 25

Durkheim E., Samobójstwo, trans. K. Wakar, Warszawa 2011

Kulmiński R., Tu pali się ktoś, Kraków 2017

Tischner J., Myśmy tej śmierci nie przemyśleli, „Kwartalnik Filmowy" 1993, no. 1

Zych R., Tragiczna śmierć Ryszarda Siwca - kres czy poczatek?, [in:] Ryszard Siwiec. Pro memoria, ed. R. Brzostowski, M. Zemło, Tarnów, Dębica 2015 